E3S Web of Conferences 1, 32006 (2013)

DOI: $10.1051 / \mathrm{e} 3 \operatorname{sconf} / 20130132006$

(C) Owned by the authors, published by EDP Sciences, 2013

\title{
Heavy metals concentration in water and sediments of the Prut River lower sector
}

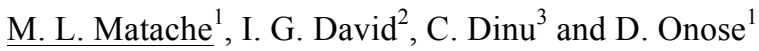 \\ ${ }^{1}$ Centre for Environmental Research and Impact Studies, University of Bucharest, Bucharest, ROMANIA, \\ media@portiledefier.ro \\ 2 Department of Analytical Chemistry, University of Bucharest, Bucharest, ROMANIA, i_g_david@yahoo.com \\ ${ }^{3}$ National Research and Development Institute for Industrial Ecology - ECOIND, Bucharest, ROMANIA
}

\begin{abstract}
A $120 \mathrm{~km}$ sector of the Prut River, Eastern Romania, was surveyed for the concentration of four heavy metals $(\mathrm{Cd}, \mathrm{Cu}, \mathrm{Pb}$ and $\mathrm{Zn})$ in water and sediments samples. The analysed sector is located on the border between Romania and Moldova and it is part of the Lower Prut Floodplain Natural Park. The most important steel-producing factory in Romania is located in the park vicinity. Four campaigns have been performed for water collection during different river regimes (both flooding and drought). The water quality is an essential condition for the wetland ecosystems within the park area and the aquatic biota they support, as trace elements bioaccumulation along the food webs might appear (David et al., 2012). Sediments can provide useful information regarding mid- and long-term pollution of the aquatic bodies, being capable of sequestering and releasing important amounts of heavy metals depending on the river regime and extreme situations (van Gestel, 2008; Verhoeven, 2009). For the sediments samples, there is an ascendant trend from upstream to the junction with the Danube River, as the distance to the main urban pole approaches, consequence of a strong human insertion. Romanian standards were used for comparison (MEWM, 2006).
\end{abstract}

Key words: Heavy metals, wetlands, water, sediments

\section{Acknowledgements}

This study was supported by the Romanian Ministry of Education, Research, Youth and Sport through the PN II project no. 32111/2008.

Dr. Marius Matache was supported by the strategic grant POSDRU/89/1.5/S/58852, Project "Postdoctoral programme for training scientific researchers" cofinanced by the European Social Found within the Sectorial Operational Program Human Resources Development 2007 - 2013.

\section{References}

Van Gestel, CAM. Physico-chemical and biological parameters determine metal bioavailability in soils.
Sci Tot Env 2008; 406: 385- 395

Verhoeven JTA. Wetland Biogeochemical Cycles and their Interactions, In: The Wetlands Handbook, Maltby E., Barker T. (Eds.) 2009, Wiley-Blackwell, Oxford, 266-281.

David, IG, Matache ML, Tudorache, A, Chisamera, G, Rozylowicz, L, Radu, GL, Food chain biomagnification of heavy metals in samples from the Lower Prut Floodplain Natural Park. Environ Eng Manag J 2012; 11: 69-74

Ministry of Environment and Water Management, (MEWM). Order of the Minister for Environment and Water Management no 161 for the approval of the norms regarding freshwater classification for establishing the ecological status of water bodies. Romanian Official Bulletin 2006; 511 bis: 2 - 92. 